\title{
On the Activities of Pancreatic Proteases and Alpha-1 Proteinase Inhibitor in Meat-Type Chicken
}

\author{
Vladimir G. Vertiprakhov*, Alena A. Grozina, Ivan A. Egorov, Tatiana N. Lenkova, \\ Vardges A. Manukyan, Tatiana A. Egorova
}

Federal Scientific Center, “All-Russian Research and Technological Poultry Institute” of Russian Academy of Sciences, Moscow, Russia

Email: *vertiprakhov63@mail.ru

How to cite this paper: Vertiprakhov, V.G., Grozina, A.A., Egorov, I.A., Lenkova, T.N., Manukyan, V.A. and Egorova, T.A. (2017) On the Activities of Pancreatic Proteases and Alpha-1 Proteinase Inhibitor in Meat-Type Chicken. Open Journal of Animal Sciences, 7, 289-296.

https://doi.org/10.4236/ojas.2017.73022

Received: May 11, 2017

Accepted: July 9, 2017

Published: July 12, 2017

Copyright $\odot 2017$ by authors and Scientific Research Publishing Inc. This work is licensed under the Creative Commons Attribution International License (CC BY 4.0).

http://creativecommons.org/licenses/by/4.0/

\begin{abstract}
The study was aimed at the evaluation of the effects of breed, age, different digestion stimulators, and dietary crude protein (CP) level on the activities of proteolytic enzymes in pancreatic tissue and duodenal chymus (in vivo), serum trypsin and $\alpha_{1}$-proteinase inhibitor (A1PI) concentrations in meat-type chicks. The study of age dynamics of trypsin and A1PI concentrations was performed on the chicks of hybrid cross "Smena-8" and two parental lines (Plymouth Rock and Cornish) fed standard commercial corn-wheat-SBM diets. Twenty birds per breed were euthanized at 1, 7, 14, 21, 28 and 35 days of age to obtain blood samples and pancreatic homogenate. Experiments on the effects of different digestion promotors (probiotic, acidifier, phytobiotic, enzymatic preparation) and different CP levels (finisher diet, CP 20\%, vs. ground corn, $\mathrm{CP}$ 8.5\%) were performed on 12 hybrid chicks with fistulated duodenum from 14 to 50 days of age. The following conclusions were made: 1) At 1 day of age high proteolytic activity in pancreatic tissue and maximal serum concentrations of trypsin and A1PI were found in both hybrid and parental lines. Since 7 to 35 days of age A1PI concentration was nearly constant, serum trypsin concentration decreased while proteolytic activity in pancreatic tissue exhibited undulate increase; 2) Proteolytic activity in pancreatic tissue was higher in hybrids compared to the parental lines from 7 to 35 days of age $(p<0.05)$; 3$)$ Supplementation of diet with exogenous enzymes stimulated the digestion due to the increase in protease activity in duodenal chymus by $9.1 \%$ compared to unsupplemented control $(\mathrm{p}<0.05)$; 4) Proteolytic activity in duodenal chymus significantly responded to the substitution of ground corn for the complete diet by 2 -fold decrease while serum trypsin concentration responded by 2.5 -fold increase $(\mathrm{p}<0.001)$. This fact can indicate that physio-
\end{abstract}


logical functions of digestive proteases are not confined to the digestive processes.

\section{Keywords}

Chicks, Pancreas, Trypsin, Alpha-1 Proteinase Inhibitor (Antitrypsin), Serum, Duodenal Fluid

\section{Introduction}

The pancreas is a mixed gland performing both exocrine and endocrine functions: exocrine function is related to the production of digestive enzymes releasing within the pancreatic juice and entering the duodenum to hydrolyze essential dietary nutrients while endocrine function is related to production of hormones participating in metabolic regulation. Recent data prove that the digestive pancreatic enzymes partially enter the bloodstream [1] [2] though their role in the circulation remains unclear. Laporte and Tremolieres [3] have suggested that this role can be related to the regulation of pancreatic enzyme secretion: the more circulatory trypsin concentration, the less amounts of enzymes will be secreted within the juice, and vice versa; trypsin regulating circulatory factor in their hypothesis was cholecystokinin CCK (pancreozymin). Some authors also have suggested the existence of CCK-independent feedback regulation of pancreatic secretion mediated by intestinal trypsin in human [4].

There might be a cycle of proteolytic enzymes within the body, as a part of the enteropancreatic circulation of the digestive enzymes [5]. Trypsinogen entering the duodenum within the pancreatic juice is activating to trypsin by duodenal enzyme enterokinase; in the intestine trypsin hydrolyzes proteins and peptides to amino acids (for subsequent absorption into the bloodstream and lymph) with partial absorption of trypsin itself into the serum where its activity will be inhibited with possible partial return of the inactivated trypsin into the pancreas.

It is presently well established that protease inhibiting activity in serum is related to different inhibitors specifically or non-specifically affecting different proteases. One of the most physiologically important and hence well studied inhibitors is $\alpha_{1}$-proteinase inhibitor (A1PI), or antitrypsin. This non-specific serpin have been believed to be responsible for $70 \%$ to $90 \%$ of antitryptic serum activity though later it was found that certain proteases of inflammatory cells (especially neutrophil elastase) are more important targets for A1PI [6].

There is still a lack of poultry related research on the interrelationships between trypsin concentrations in pancreatic juice and serum and between trypsin and its inhibitors in serum [2]. The study presented was aimed at the evaluation of the effects of breed, age, different digestion stimulators, and dietary crude protein level on the activities of proteolytic enzymes in pancreatic tissue, duodenal chymus (in vivo), and serum, and on serum A1PI concentration in meattype chicks. 


\section{Materials and Methods}

\subsection{Poultry and Diets}

The experimental study of age dynamics of trypsin and A1PI concentrations and activities in meat-type chicks was performed on the chicks of hybrid cross "Smena- 8 " and two parental lines (Plymouth Rock and Cornish) housed in the Institute's vivarium and fed standard commercial starter, grower, and finisher corn-wheat-SBM diets for broilers (CP 23.10; 21.21 and 20.12\%, ME 310.05; 315.13 and $320.04 \mathrm{Kcal} / 100 \mathrm{~g}$ respectively for growth phases $1-14 ; 15-21$ and 22 - 35 days of age). Twenty birds per breed (in two replicates of 10 birds) were euthanized at 1, 7, 14, 21, 28 and 35 days of age to obtain blood samples and pancreatic homogenate.

Blood samples after addition of anticoagulant (sodium citrate) were centrifuged at $5000 \mathrm{rpm}$ for $5 \mathrm{~min}$ to obtain the serum. In the chicks abdominal wall was dissected to withdraw the pancreas; the latter was weighed and homogenized at $1500 \mathrm{rpm}$ for $3 \mathrm{~min}$ with cold Ringer's solution. Then the homogenates were treated with the extract of duodenal mucosa to activate proteases by its enterokinase for subsequent activity analysis.

Experiments on the effects of different digestion promoting feed additives (probiotic, acidifier, phytobiotic, enzymatic preparation) and different $\mathrm{CP}$ levels on duodenal protease activity, trypsin and A1PI concentrations in serum were performed on fistulated hybrid chicks from 14 to 50 days of age. Twelve "Smena- 8 " chicks were operated at 14 days of age using sedative (Zoletil) and local anesthesia (novocaine $0.5 \%$ ) to transplant the $\mathrm{T}$-shaped fistulae into the duodenum near Meckel's diverticulum (Figure 1). After 3 - 5 days of recovery the chicks were randomly allotted to one of five diets. Unsupplemented control was fed the same aforementioned finisher diet (basic diet, or BD) and four experimental treatments were fed $\mathrm{BD}$ supplemented with the four additives during 10 days ( 2 - 3 chicks per diet); then the chicks were randomly redistributed to the same 5 dietary treatments for another 10 days. This experiment lasted from 20 to

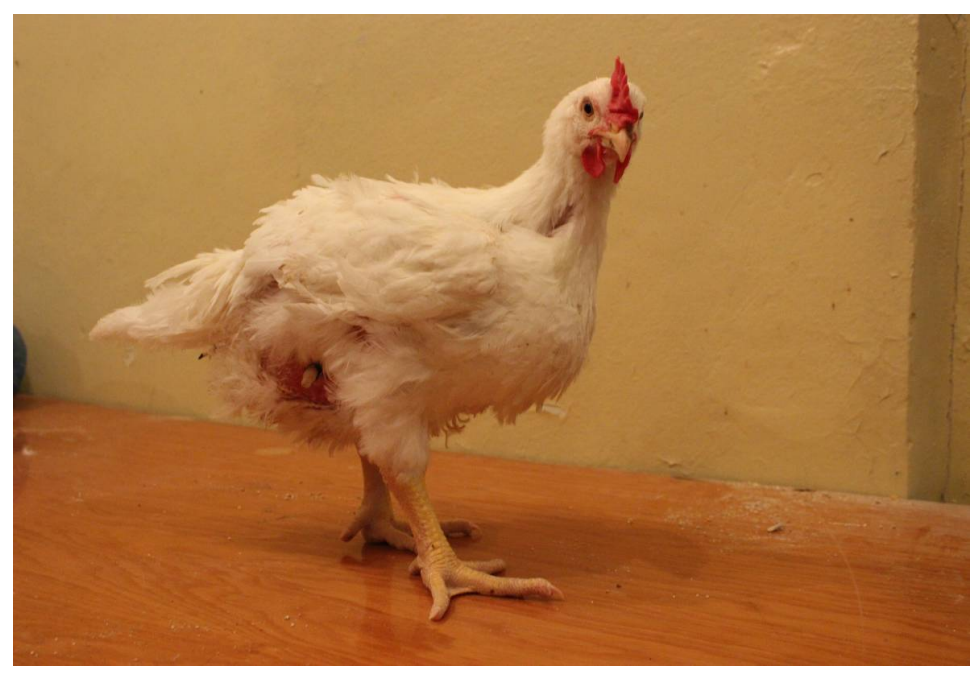

Figure 1. A hybrid chick with duodenal fistula. 
40 days of age. Every morning (after $14 \mathrm{~h}$ of starvation) the chicks were fed 1/3 of their daily feed consumption (according to breeder's recommendations); $1 \mathrm{~h}$ later the duodenal chymus was sampled $(5 \mathrm{ml})$ to determine the activity of trypsin. The blood was sampled from the axillary vein. The results were averaged on the diet basis. The additives used: probiotic ( $\mathrm{Pr}$ ) was a sporous preparation based on a Bacillus subtilis strain and Enterococci; acidifier (A) was a mixture of low-molecular organic acids; phytobiotic $(\mathrm{Ph})$ was a mixture of $B$. subtilis and a combination of different essential oils including garlic (Allium sativum $L$.); enzymatic preparation (EP) was a complex of natural live microorganisms with cellulolytic, carbohydrase, and antimicrobial activity.

The comparison of different dietary $\mathrm{CP}$ levels was performed on the same fistulated chicks ( 5 birds per treatment) from 42 to 50 days of age; control treatment was fed the same finisher diet (CP 20\%), experimental treatment was fed ground corn (CP 8.5\%). Duodenal chymus and blood were sampled daily hence there were 35 measurements ( 7 days $\times 5$ birds) per treatment.

\subsection{Biochemical Analyses}

Homogenates of pancreatic tissue, blood serum, and duodenal chymus were analyzed for proteolytic activity using the decrease in substrate concentrations (casein) determined via colorimetric detection [7]. Serum protease activity was determined using benzoyl-DL-arginine-p-nitroanilide (BAPNA) as a substrate on semi-automatic biochemical analyzer BS3000P (China) [8] .

Serum A1PI concentration was determined on automatic biochemical analyzer ChemWell-T 2900 (USA) using specific reagent kit (APTEC Diagnostics, Belgium). Serum samples $(10 \mu \mathrm{l})$ were diluted 1:10 with the normal saline solution $(9 \mathrm{~g} / \mathrm{l})$ and then $300 \mu \mathrm{l}$ of buffer solution (the mixture of phosphate buffered saline ( $\mathrm{pH}$ 7.43), polyethylene glycol $60 \mathrm{~g} / \mathrm{l}$, and sodium azide $0.95 \mathrm{~g} / \mathrm{l}$ ) was added. The resulting mixture was incubated for $2 \mathrm{~min}$ at $37^{\circ} \mathrm{C}$. Then antiserum $(20 \mu \mathrm{l})$ was added (the same phosphate buffered saline, polyclonal caprine antibodies to human A1PI $2.0 \mathrm{mg} / \mathrm{ml}$, sodium azide $0.95 \mathrm{~g} / \mathrm{l}$ ); the resulting mixture was incubated for $5 \mathrm{~min}$ at $37^{\circ} \mathrm{C}$. A1PI concentrations were determined via differences in absorbance with $340 \mathrm{~nm}$ and differential $450 \mathrm{~nm}$ filters.

The results were analyzed statistically using Microsoft Excel software and paired t-test for calculation of the p-values.

\section{Results and Discussion}

The data on age dynamics of proteolytic and antitryptic activities in the pancreas and serum showed that proteolytic activity in pancreatic tissue undergoes undulate changes with the growth of the chicks (Table 1(a)). At 1 day of age high level of protease activity was found indicating the readiness of the digestive system for effective digestion and absorption of dietary protein in neonatal chicks of all 3 genotypes studied. At 7 days of age an abrupt decrease in proteolytic activity was recorded (by $49.8 \%$ on average) with subsequent increase to 14 days of age to the level of 1 day of age. The decrease at 7 days was maximal in Plymouth 
Table 1. Age dynamics of protease activity in pancreatic tissue and trypsin activity and A1PI concentration in serum in different lines of meat-type chicks.

\begin{tabular}{|c|c|c|c|c|c|c|}
\hline & \multicolumn{6}{|c|}{ Age, $d$} \\
\hline & 1 & 7 & 14 & 21 & 28 & 35 \\
\hline \multicolumn{7}{|c|}{ (a) Protease activity in pancreatic tissue, $\mathrm{mg} / \mathrm{ml} / \mathrm{min}$} \\
\hline average & $299 \pm 27.5$ & $150 \pm 14.9^{\star}$ & $246 \pm 13.5$ & $229 \pm 28.7$ & $252 \pm 24.0$ & $431 \pm 31.5^{*}$ \\
\hline hybrids & $323 \pm 30.7$ & $200 \pm 12.1^{\star a}$ & $317 \pm 48.9^{\mathrm{a}}$ & $278 \pm 30.1$ & $325 \pm 46.9^{\mathrm{a}}$ & $487 \pm 43.2^{*}$ \\
\hline Plymouth Rock & $314 \pm 21.1$ & $125 \pm 15.7^{\star b}$ & $246 \pm 32.2$ & $192 \pm 50.0^{*}$ & $206 \pm 22.6^{\star b}$ & $402 \pm 32.2^{*}$ \\
\hline Cornish & $261 \pm 36.1$ & $126 \pm 14.1^{\star b}$ & $175 \pm 26.6^{\mathrm{b}}$ & $217 \pm 68.6$ & $226 \pm 24.7$ & $403 \pm 87.4$ \\
\hline \multicolumn{7}{|c|}{ (b) Trypsin activity in serum, U/L } \\
\hline average & $206 \pm 12.0$ & $23 \pm 1.9^{*}$ & $29 \pm 1.3^{*}$ & $25 \pm 1.4^{*}$ & $19 \pm 0.5^{*}$ & $17 \pm 1.6^{*}$ \\
\hline hybrids & $224 \pm 12.1$ & $19 \pm 4.3^{*}$ & $29 \pm 3.9^{*}$ & $23 \pm 2.1^{*}$ & $19 \pm 1.4^{*}$ & $23 \pm 3.6^{\star a}$ \\
\hline Plymouth Rock & $191 \pm 11.2$ & $21 \pm 1.9^{*}$ & $30 \pm 1.4^{*}$ & $23 \pm 3.2^{*}$ & $20 \pm 1.4^{\star}$ & $12 \pm 2.5^{\star b}$ \\
\hline Cornish & $203 \pm 12.7$ & $29 \pm 5.2^{*}$ & $30 \pm 3.7^{*}$ & $29 \pm 3.6^{*}$ & $18 \pm 1.2^{*}$ & $16 \pm 1.1^{*}$ \\
\hline \multicolumn{7}{|c|}{ (c) A1PI concentration in serum, $\mathrm{mg} / \mathrm{dL}$} \\
\hline average & $20.2 \pm 0.30$ & $14.6 \pm 0.43^{*}$ & $14.0 \pm 0.32$ & $14.2 \pm 0.44$ & $13.6 \pm 0.41$ & $15.1 \pm 0.20^{*}$ \\
\hline hybrids & $19.9 \pm 0.35$ & $14.3 \pm 0.38^{*}$ & $14.3 \pm 0.34^{*}$ & $15.3 \pm 0.89^{*}$ & $13.2 \pm 0.53^{*}$ & $15.1 \pm 0.52^{*}$ \\
\hline Plymouth Rock & $20.8 \pm 0.45$ & $15.3 \pm 0.77^{\star}$ & $13.6 \pm 0.52^{\star}$ & $14.3 \pm 0.69^{*}$ & $14.1 \pm 0.89^{*}$ & $14.8 \pm 0.33^{\star}$ \\
\hline Cornish & $20.0 \pm 0.40$ & $14.3 \pm 0.52^{*}$ & $14.1 \pm 0.44^{*}$ & $13.1 \pm 0.29^{*}$ & $13.6 \pm 1.38^{*}$ & $15.3 \pm 0.59^{*}$ \\
\hline
\end{tabular}

*-figures within a row marked with "*” significantly differ from respective parameter at 1 day of age, $\mathrm{P}<0.05$. ${ }^{\mathrm{a}, \mathrm{b}}$-figures within a column with different superscripts differ significantly, $\mathrm{P}<0.05$.

Rock parental line (by $60.2 \%$ compared to 1 day of age). Proteolytic activity in pancreatic tissue at 7 days of age significantly differed between the lines: the activity in hybrids was higher compared to the parental lines (by $37.5 \%$ compared to Plymouth Rock line and by $37.0 \%$ compared to Cornish line, $\mathrm{p}<0.05)$. From 14 to 28 days of age no substantial changes in pancreatic proteolytic activities were found; at 35 days of age, however, there was an average increase by $44.1 \%$ compared to 1 day of age. There was also a significant difference $(\mathrm{p}<0.05)$ between hybrids and Plymouth Rocks at 28 days of age: proteolytic activity in the pancreas was higher by $36.6 \%$ in hybrids.

Serum trypsin activity followed similar undulate age dynamics (Table 1(b)). At 1 day of age serum trypsin activity was the most high in all three lines; it was presumably related to the adaptation of the pancreas to the shift in nutrition from the consumption of highly digestible nutrients from the residual yolk to exogenous diet. We assume that the pancreas in neonatal chicks is yet unable to synthesize de novo sufficient amounts of digestive enzymes and hence an intense recretion of trypsin from the circulation to the pancreas can occur with subsequent release of this recreted enzyme (together with newly synthesized) within the pancreatic juice [9]. At 7 days of age an abrupt decrease in serum trypsin activity was recorded with average decrease of $88.8 \%$ compared to 1 day of age. After the slight increase at 14 days of age serum trypsin activity declined to 35 days of age by average $91.8 \%$ compared to 1 day of age. Significant differences between the genotypes were found only at 35 days of age: the highest trypsin ac- 
tivity was found in hybrids while the least was found in Plymouth Rock line (by $52.1 \%$ compared to hybrids).

The data on serum A1PI activity (Table 1(c)) showed that it was maximal at 1 days of age with subsequent significant decrease at 7 days of age (by $27.7 \%$ on average) and maintaining of these decreased levels to 35 days of age. No breed related differences in A1PI activity were found.

The results on the influence of different feed additives on the activities of trypsin in duodenal chymus and serum and on the serum A1PI activity are presented in Table 2 . These data showed that only enzyme preparation significantly increased trypsin activity in duodenal chymus (by $9.1 \%, \mathrm{p}<0.05$ ). Supplementation of diet with acidifier and phytobiotic increased serum trypsin activity in compare to control by $82.7 \%$ and $41.4 \%$ respectively; probiotic additive decreased serum trypsin activity by $27.6 \%$ compared to control while enzymatic additive led to an insignificant increase by $20 \%$.

Since there was no substantial response of trypsin activity in pancreatic homogenate (data not presented) and in duodenal chymus (Table 2) to different digestion promoters while serum trypsin activity was affected significantly it can be assumed that it is serum trypsin activity that can be a reliable marker of pancreatic (and to some extent intestinal) functionality and health status in poultry. E.g. in human reduced or increased serum trypsin concentrations are used as markers of pancreatic functionality and disease [10].

The effects of different dietary CP levels on the activities of trypsin and A1PI was studied on fistulated broiler chicks fed standard finisher diet as high protein diet or ground corn as low protein diet (Table 3). Proteolytic activity in duodenal chymus significantly $(\mathrm{p}<0.001)$ responded to low-protein diet by 2 -fold decrease while serum trypsin concentration responded by 2.5 -fold increase compared to high-protein diet $(\mathrm{p}<0.001)$. These alterations of trypsin activities can indicate certain abrupt metabolic changes in the entire digestive process and even beyond the digestion since it is well established that serum trypsin is involved

Table 2. Activities of proteases in duodenal chymus and serum and concentration of A1PI in serum in broilers fed diets with different digestion promoters.

\begin{tabular}{cccccc}
\hline & \multicolumn{5}{c}{ Treatment } \\
\cline { 2 - 5 } Parameter & $\begin{array}{c}\text { Control } \\
(\mathrm{BD})\end{array}$ & $\mathrm{BD}+\mathrm{Pr}^{1}$ & $\mathrm{BD}+\mathrm{A}$ & $\mathrm{BD}+\mathrm{Ph}$ & $\mathrm{BD}+\mathrm{EP}$ \\
\hline $\begin{array}{c}\text { Protease activity in duodenal } \\
\text { chymus, mg/ml/min }\end{array}$ & $33 \pm 1.0$ & $31 \pm 0.9$ & $32 \pm 1.4$ & $33 \pm 1.3$ & $36 \pm 0.6^{*}$ \\
$\begin{array}{c}\text { Trypsin activity in serum, U/1 } \\
\text { A1PI concentration } \\
\text { in serum, mg/dl }\end{array}$ & $29 \pm 2.0$ & $21 \pm 2.9^{*}$ & $53 \pm 5.3^{\star}$ & $41 \pm 3.8^{*}$ & $35 \pm 2.3$ \\
& $17.5 \pm 0.65$ & $18.1 \pm 1.25$ & $18.2 \pm 0.10$ & $18.2 \pm 0.20$ & $18.7 \pm 1.35$
\end{tabular}

*-figures within a row marked with “*” significantly differ from respective parameter in control, $\mathrm{P}<0.05$. ${ }^{1}$ The additives used for supplementation of basic diet (BD): probiotic (Pr) was a sporous preparation based on a Bacillus subtilis strain and Enterococci; acidifier (A) was a mixture of low-molecular organic acids; phytobiotic $(\mathrm{Ph})$ was a mixture of $B$. subtilis and a combination of different essential oils including garlic (Allium sativum L.); enzymatic preparation (EP) was a complex of natural live microorganisms with cellulolytic, carbohydrase, and antimicrobial activity. 
Table 3. Protease activity in duodenal chymus, activity of trypsin and concentration of A1PI in serum in broilers fed diets with high vs. low CP levels.

\begin{tabular}{cccc}
\hline Parameters & CP 20\% & CP 8.5\% & Difference, \% \\
\hline Protease activity in duodenal chymus, $\mathrm{mg} / \mathrm{ml} / \mathrm{min}$ & $33 \pm 1.0$ & $16 \pm 0.7$ & $-48.5^{*}$ \\
Trypsin activity in serum, U/l & $35 \pm 2.3$ & $85 \pm 8.7$ & $+242.8^{*}$ \\
A1PI concentration in serum, $\mathrm{mg} / \mathrm{dl}$ & $17.5 \pm 0.65$ & $17.9 \pm 0.29$ & +102.3 \\
\hline
\end{tabular}

${ }^{*}-\mathrm{p}<0.001$.

into the vasotonic regulation due to the ability of releasing of vasoactive (hypotensive) peptide bradykinin [11]. These metabolic changes can improve nutrient assimilation; earlier we showed (Table 1(b)) that serum trypsin activity was the highest during the neonatal growth phase in broilers when FCR is the lowest compared to later age periods.

Serum A1PI activity didn't respond to digestion promoters and dietary protein level (Table 2 and Table 3); this fact can be the further evidence of the absence of sustained correlation between serum trypsin and A1PI levels in chicken.

\section{Conclusions}

1) At 1 day of age high proteolytic activity in pancreatic tissue and maximal serum concentrations of trypsin and A1PI were found in meat-type chicks of both hybrid and parental lines. Since 7 to 35 days of age A1PI concentration was nearly constant, serum trypsin concentration decreased while proteolytic activity in pancreatic tissue, on the contrary, exhibited undulate increase.

2) Proteolytic activity in pancreatic tissue was higher in hybrids compared to the parental lines from 7 to 35 days of age.

3) Supplementation of diet with exogenous enzymes was found to stimulate the digestion due to the increase in protease activity in duodenal chymus by 9.1\% compared to unsupplemented control.

Proteolytic activity in duodenal chymus significantly responded to the substitution of ground corn (CP 8.5\%) for the complete diet (CP 20.0\%) by 2 -fold decrease while serum trypsin concentration responded by 2.5 -fold increase $(\mathrm{p}<$ 0.001). This fact can indicate that physiological functions of digestive proteases are not confined to the digestive processes per se and that these enzymes could be involved into the body-level regulation of protein metabolism and pancreatic adaptation to feed quality.

\section{Acknowledgements}

The study was financed by Russian Science Foundation, grant No 16-16-04089.

\section{References}

[1] Korot'ko, G.F. (2013) Formation of Enzyme Component of Digestive Glands (Review). Physical Training \& Sports-Science \& Practice, 1, 51-57. (in Russian)

[2] Vertiprakhov, V.G., Grozina, A.A. and Dolgorukova, A.M. (2016) The Activity of Pancreatic Enzymes on Different Stages of Metabolism in Broiler Chicks. Agricul- 
tural Biology (Sel'skokhozyaistvennaya Biologiya, Moscow), 51, 509-515. (in Russian) https://doi.org/10.15389/agrobiology.2016.4.509rus

[3] Laporte, J.C. and Tremolieres, J. (1971) Regulation hormonale de la sécrétion enzymatique du pancréas exocrine. Comptes rendus de l'Académie des Sciences, Series $D, 273,1205-1207$.

[4] Layer, P., Jansen, J.B.M.J., Cherian, L., Lamers, S.B.H.W. and Goebell, H. (1990) Feedback Regulation of Human Pancreatic Secretion: Effects of Protease Inhibition on Duodenal Delivery and Small Intestinal Transit of Pancreatic Enzymes. Gastroenterology, 98, 1311-1319. https://doi.org/10.1016/0016-5085(90)90350-A

[5] Rothman, S., Leibow, C. and Isenman, L. (2002) Conservation of Digestive Enzymes. Phsyological Reviews, 82, 1-18.

https://doi.org/10.1152/physrev.00022.2001

[6] Gettins, P.G. (2002) Serpin Structure, Mechanism, and Function. Chemical Reviews, 102, 4751-4804. https://doi.org/10.1021/cr010170+

[7] Batoev, T.Z. (1971) Photometric analysis of Proteolytic Enzymatic Activities in Pancreas and Its Juice Using the Decrease in Casein Concentration as a Criterion. The Proceedings of Buryat Agricultural Institute, 25, 122-126. (in Russian)

[8] Mikhailova, A.G., Khairullin, R.F., Rumsh, L.D., Demidyuk, I.V., Kostrov, S.V., Grinberg, N.V., Burova, T.V. and Grinberg, V.Y. (2014) Cloning, Sequencing, Expression, and Characterization of Thermostability of Oligopeptidase B from Serratia Proteamaculans, a Novel Psychrophilic Protease. Protein Expression and Purification, 93, 63-76. https://doi.org/10.1016/j.pep.2013.10.011

[9] Korot'ko, G.F. (2003) Recretion of Enzymes and Hormones by Exocrine Glands. Uspekhi Fisiologicheskikh Nauk, 34, 21-32. (in Russian)

[10] Heinrich, H.C., Gabbe, E.E. and Icaqić, F. (1979) Immunoreactive Serum Trypsin in Diseases of the Pancreas. Klinische Wochenschrift, 57, 1237-1238. https://doi.org/10.1007/BF01489252

[11] Prado, J.L. (1970) Proteolytic Enzymes as Kininogenases. In: Erdös, E.G. and Wilde, A.F., Eds., Bradykinin, Kallidin and Kallicrein, Springer-Verlag, New York, 162163. https://doi.org/10.1007/978-3-642-46222-1_8

\section{Submit or recommend next manuscript to SCIRP and we will provide best service for you:}

Accepting pre-submission inquiries through Email, Facebook, LinkedIn, Twitter, etc. A wide selection of journals (inclusive of 9 subjects, more than 200 journals)

Providing 24-hour high-quality service

User-friendly online submission system

Fair and swift peer-review system

Efficient typesetting and proofreading procedure

Display of the result of downloads and visits, as well as the number of cited articles

Maximum dissemination of your research work

Submit your manuscript at: http://papersubmission.scirp.org/

Or contact ojas@scirp.org/ 